\title{
The role of XCR1 and its ligand XCL1 in antigen cross-presentation by murine and human dendritic cells
}

\section{Richard A. Kroczek* and Volker Henn}

Molecular Immunology, Robert Koch-Institute, Berlin, Germany

\section{Edited by:}

Christian Kurts,

Friedrich-Wilhelms-Universität Bonn, Germany

Reviewed by:

Francesca Granucci, University of Milano-Bicocca, Italy

Thomas Gebhardt, The University of Melbourne, Australia

\section{${ }^{*}$ Correspondence:}

Richard A. Kroczek, Molecular

Immunology, Robert Koch-Institute,

Nordufer 20, 13353 Berlin, Germany.

e-mail:kroczek@rki.de
Recently, the chemokine receptor XCR1 has been found to be exclusively expressed on a subset of dendritic cell (DC) known to be involved in antigen cross-presentation. This review aims to summarize the known biology of the XCR1 receptor and its chemokine ligand XCL1, both in the mouse and the human. Further, any involvement of this receptorligand pair in antigen uptake, cross-presentation, and induction of innate and adaptive cytotoxic immunity is explored. The concept of antigen delivery to DC via the XCR 1 receptor is discussed as a vaccination strategy for selective induction of cytotoxic immunity against certain pathogens or tumors.

Keywords: dendritic cells, XCR1, XCL1, antigen cross-presentation, antigen targeting, vaccination
Recently, the chemokine receptor XCR1 has been found to be exclusively expressed on a subset of dendritic cells (DCs) known to excel in antigen cross-presentation. The impact of this chemokine receptor on DC biology can only be understood through combining the available knowledge on the XCR1 receptor, its chemokine ligand XCL1, and the current information on the function of DCs expressing XCR1.

The chemokine ligand XCL1 has been cloned independently by three groups, by Kelner et al. (1994) as "lymphotactin" from murine immature thymocytes, by Müller et al. (1995) as "ATAC" ("activation-induced, $\mathrm{T}$ cell-derived, and chemokine-related molecule") from two-signal activated human T cells, and by Yoshida et al. (1995), who identified "single cysteine molecule-1" ("SCM1," huXCL1) in PHA-stimulated human PBMC. The latter group later also found a second human gene, termed SCYC2 (Yoshida et al., 1996), which encodes huXCL2, a protein differing only in amino acids 7 and 8 from the originally identified SCM- 1 molecule, redesignated to SCM- $1 \alpha$. Interestingly, a gene corresponding to human SCYC2/XCL2 has never been identified in the mouse. Dorner et al. (1997) purified human ATAC, determined its mature protein form, and demonstrated that it is secreted as a partially glycosylated 93 aa protein with a calculated $M_{r}$ of $10.3 \mathrm{kDa}$. Mature human ATAC corresponds in its sequence to SCM- $1 \alpha$, and is $61.4 \%$ identical and $84 \%$ similar (NCBI blastp) to murine lymphotactin. Collectively, these three groups thus defined the nature of murine XCL1 and human XCL1 (SCM-1 $1 \alpha)$ XCL2 $(\mathrm{SCM}-1 \beta)$.

The generation of $\mathrm{mAb}$ specific for murine ATAC/XCL1 provided the first information on the biological context of XCL1 secretion. In vitro activated murine NK cells, Th1-polarized CD4 ${ }^{+}$ $\mathrm{T}$ cells, and $\mathrm{CD} 8^{+} \mathrm{T}$ cells were found to co-secrete ATAC/XCL1 with IFN- $\gamma$, MIP- $1 \alpha$, MIP- $1 \beta$, and RANTES (Dorner et al., 2002), prototypical components of the Th1 immune defense (Moser and Loetscher, 2001). Further, the same co-secretion pattern was observed in vivo by NK cells in the early phase, and by antigen-specific $\mathrm{CD}^{+} \mathrm{T}$ cells in the later adaptive phase of murine listeriosis (Dorner et al., 2002), a disease in which the intracellular pathogen is cleared by a Th1-type immune reaction (Pamer, 2004). Together, these expression data strongly indicated the involvement of ATAC/XCL1 in the Th1 immune defense, but did not yet provide a mechanistic model of ATAC/XCL1 action.

The function of XCL1 remained unclear for many years. Kelner et al. (1994) reported in their original publication that their newly identified protein induced chemotaxis of a variety of lymphocytes, hence their designation "lymphotactin." In the years following the cloning of lymphotactin/ATAC/SCM-1, a plethora of reports on the chemotactic action of XCL1 was published, both in the human and the mouse. These, as it later turned out, erroneous reports, claimed chemotaxis on T cells, B cells, NK cells, neutrophils, and other cell types (listed in Supplemental Table S1 of Dorner et al., 2009). Only few groups reported that they failed to observe any chemotaxis using a broad array of cell types (Bleul et al., 1996; Dorner et al., 1997; Johnston et al., 2003).

A major step forward was the identification of the receptor for XCL1 by the group of Yoshie. They matched a previously cloned human orphan G protein-coupled receptor GPR5 (Heiber et al., 1995) with the orphan human chemokines SCM-1 $\alpha$ XCL1 and SCM-1 $\beta / X C L 2$, employing binding and functional assays (Yoshida et al., 1998). Further work also indicated that GPR5, later officially designated XCR1, is the only receptor for XCL1 (Yoshida et al., 1998; Shan et al., 2000).

Usually, the identification of a receptor for a chemokine strongly facilitates the elucidation of the biological role of a given chemokine-receptor system, but not in this case. Since a XCR1specific $\mathrm{mAb}$ was not available at that time, the detection of XCR1 expression in tissues had to be done by RT-PCR. The original description of the murine XCR1 gene assumed the existence of only a single-exon coding for XCR1 (Yoshida et al., 1999), so detection of XCR1 mRNA had to rely on a "single-exon" RT-PCR, a system highly prone to false positive results. As a result, more than 
a dozen publications reported the expression of XCR1 in a great variety of cell types, all of which turned out to be incorrect (listed in Supplemental Table S2 of Dorner et al., 2009).

The breakthrough regarding the expression of XCR1 came from studies employing poly (A) RNA for detection of XCR1 by RTPCR and the recognition that the murine XCR1 gene contains two exons, allowing the use of an "intron-spanning" RT-PCR. This approach revealed that XCR1 mRNA is selectively expressed in "conventional" DCs, and not in resting or activated T cells, B cells, NK cells, or plasmacytoid DCs (pDCs). A more detailed analysis showed that only $\mathrm{CD} 8^{+} \mathrm{DCs}$ and a small proportion of $\mathrm{CD} 8^{-}$ DCs express XCR1 mRNA (Dorner et al., 2009). These expression studies were corroborated by experiments using a reporter mouse, in which lacZ is expressed under the control of the XCR1 promoter. Whole-body histological analysis of this reporter mouse yielded signals compatible with the notion that XCR1 is exclusively expressed in DCs and not in other cells. In the spleen, the XCR1 signal was associated with $\mathrm{CD}^{+}$DCs in the red pulp and in T cell zones (Dorner et al., 2009; Crozat et al., 2010). In lymph nodes, XCR1 gene expression was identified in paracortical areas and subcapsular sinuses (Dorner et al., 2009) and was found to be highly associated with CD103 expressed by migratory DCs (Crozat et al., 2011).

Functional studies yielded results congruent with the obtained $\mathrm{XCR} 1$ receptor expression profile. XCL1 induced strong chemotaxis of murine $\mathrm{CD} 8^{+} \mathrm{DCs}$, but not of other DC subtypes, T cells, B cells, or NK cells (Dorner et al., 2009). These experiments thus for the first time clearly defined XCL1 as a chemokine and revealed an unusually restricted target population, the $\mathrm{CD} 8^{+}$DCs. In a series of experiments, the function of XCR1 and its chemokine ligand was then tested in vivo. When antigen was targeted to APC via DEC-205 in mice, adoptively transferred CD8 ${ }^{+}$OT-I T cells became activated by the cross-presented antigen and started to secrete XCL1. Further, studies employing XCL1 gene-deficient mice revealed that XCL1 optimizes the expansion and survival of these OT-I CD8 ${ }^{+} \mathrm{T}$ cells and their subsequent differentiation into cytotoxic cells. Collectively, this study demonstrated the involvement of the XCL1-XCR1 axis in the dialog of $\mathrm{CD}^{+} \mathrm{T}$ cells with $\mathrm{CD}^{+}$DCs on their way to become cytotoxic T cells (Dorner et al., 2009).

$\mathrm{CD}^{+}$DCs in the mouse spleen are part of the "resident" DC population, which make up the large majority of splenic DCs. Resident DCs take up antigen locally and present it to T cells "on site.” Resident DCs, which all express the CD11c cell surface protein, have been classically subdivided into CD ${ }^{+}$DCs $\left(C D 11 b^{\text {hi }}\right.$ $\mathrm{CD}^{+} \mathrm{CD}^{-} \mathrm{CD}^{-05} 5^{\mathrm{lo}}$, around $70 \%$ of splenic DCs), $\mathrm{CD}^{+}$ DCs (CD11b $\left.{ }^{\text {lo }} \mathrm{CD}^{+} \mathrm{CD}^{205^{\mathrm{hi}}}, 20 \%\right)$, and DN DCs $\left(\mathrm{CD} 11 \mathrm{~b}^{\text {hi }}\right.$ $\mathrm{CD}^{-} \mathrm{CD}^{-}{ }^{-} \mathrm{CD}^{205^{\mathrm{lo}}}, 10 \%$; Vremec et al., 2000). In the past, resident $\mathrm{CD}^{+}$DCs have been consistently implicated in antigen cross-presentation, in which exogenous antigen is not "classically" presented in the context of MHC-class II, but instead shunted to the MHC-class I pathway (den Haan et al., 2000; Shortman and Heath, 2010).

The correlation of XCR1 expression with $\mathrm{CD}^{+}$DCs was not perfect, with only $70-85 \%$ of $\mathrm{CD}^{+}$DCs showing the XCR1 driven $L a c Z$-reporter signal, but also 2-8\% of DN DCs (Dorner et al., 2009). These data could be fully reproduced with a mAb to murine
XCR1 (unpublished data), raising questions about the functional role of the $20-25 \%$ of $\mathrm{CD}^{+}$DCs not expressing XCR1, and the 2-8\% of DN DCs positive for XCR1, but not expressing CD8. Of interest in this context, CFSE-labeled allogeneic 300-19 pre-B cells injected i.v. were essentially only taken up by XCR $1^{+}$DCs, while $\mathrm{CD}^{+}$DCs lacking XCR1 and other DCs played a negligible part (unpublished data).

The uptake studies were complemented by tests for antigen cross-presentation. Soluble ovalbumin (OVA) was injected i.v., and $14 \mathrm{~h}$ later $\mathrm{CD}^{+} \mathrm{XCR}^{+}, \mathrm{CD}^{-} \mathrm{XCR}^{+}$(corresponding to the $\mathrm{XCR} 1^{+} \mathrm{DN}$ DC subset), $\mathrm{CD}^{+} \mathrm{XCR}^{-}$, and $\mathrm{CD} 8^{-} \mathrm{XCR} 1^{-}$ DCs were highly purified from spleens and co-cultured with OT$\mathrm{I}$ in vitro. In this classical assay for antigen cross-presentation, $\mathrm{CD}^{+}{ }^{+} \mathrm{XCR}^{+}{ }^{+}$and $\mathrm{CD} 8{ }^{-} \mathrm{XCR}^{+}{ }^{+} \mathrm{DC}$ s presented soluble OVA clearly better than $\mathrm{CD} 8^{+} \mathrm{XCR} 1^{-}$and $\mathrm{CD} 8^{-} \mathrm{XCR} 1^{-} \mathrm{DCs}$ (unpublished data). When the same experiment was performed with cellassociated antigen (300-19 cells transfected with OVA), splenic $\mathrm{CD}^{+} \mathrm{XCR}^{+}$, and $\mathrm{CD} 8^{-} \mathrm{XCR} 1^{+}$DCs excelled in antigen crosspresentation, whereas $\mathrm{CD}^{+} \mathrm{XCR}^{-}$and $\mathrm{CD}^{-} \mathrm{XCR}^{-}$DCs fully failed (unpublished data). Both assays with soluble and cellassociated antigen thus demonstrated the superior capacity of the $\mathrm{XCR} 1^{+} \mathrm{DC}$ populations to cross-present antigen, irrespective of CD8 expression on their surface.

When these functional studies were followed by extensive phenotyping of these four DC populations, the XCR $1^{+} \mathrm{CD}^{+} \mathrm{DCs}$ appeared homogeneous and very similar to $\mathrm{XCR} 1^{+} \mathrm{CD} 8^{-} \mathrm{DCs}$. On the other hand, both $\mathrm{XCR}^{-}{ }^{-} \mathrm{CD} 8^{+} \mathrm{DCs}$ and $\mathrm{XCR} 1^{-} \mathrm{CD} 8^{-}$ DCs exhibited a quite different surface phenotype (unpublished data). When combining the phenotypic analysis of the various DC subsets with their ability to cross-present antigen, it becomes apparent that the current classification of DCs into $\mathrm{CD}^{+} \mathrm{DCs}$, $\mathrm{CD}^{+}{ }^{+} \mathrm{DCs}$ and DN DCs may no longer be useful. Instead, splenic $\mathrm{XCR} 1^{+} \mathrm{DCs}$ appear as a rather homogeneous population set apart from the XCR1 ${ }^{-}$DCs. The XCR1 ${ }^{-}$DC population, on the other hand, may possibly be further subdivided, e.g., based on the expression of the fractalkine receptor, as suggested recently by Bar-On et al. (2010). More functional data with DCs from other lymphoid organs will be necessary to further characterize the $\mathrm{XCR}^{+}$ and XCR1 ${ }^{-}$DC populations. However, what emerges from the current studies is the close correlation of XCR1 expression with the ability of DCs to cross-present antigen. The XCL1-XCR1 axis thus appears as an integral part of the antigen cross-presentation machinery.

How can we imagine the contribution of the XCL1-XCR1 system to the defense of pathogens? From the few in vivo studies available it is clear that NK cells, and possibly also other cells of the innate immune system, secrete this chemokine early upon infection with certain pathogens like Listeria or MCMV (Dorner et al., 2002, 2004). When NK cells release XCL1, they co-release this chemokine with a set of other cytokines and chemokines, most notably IFN- $\gamma$, as part of a Th1-type of defense (Dorner et al., 2002, 2003, 2004). It seems likely that secretion of XCL1 under these circumstances facilitates the communication of $\mathrm{NK}$ cells with XCR1 ${ }^{+}$DCs (and vice versa, Figure 1). It is interesting to note that in the adaptive phase of the immune response activated $\mathrm{CD} 8{ }^{+} \mathrm{T}$ cells communicate with $\mathrm{XCR} 1^{+} \mathrm{DCs}$ by secreting the same array of XCL1-associated cytokines and chemokines 


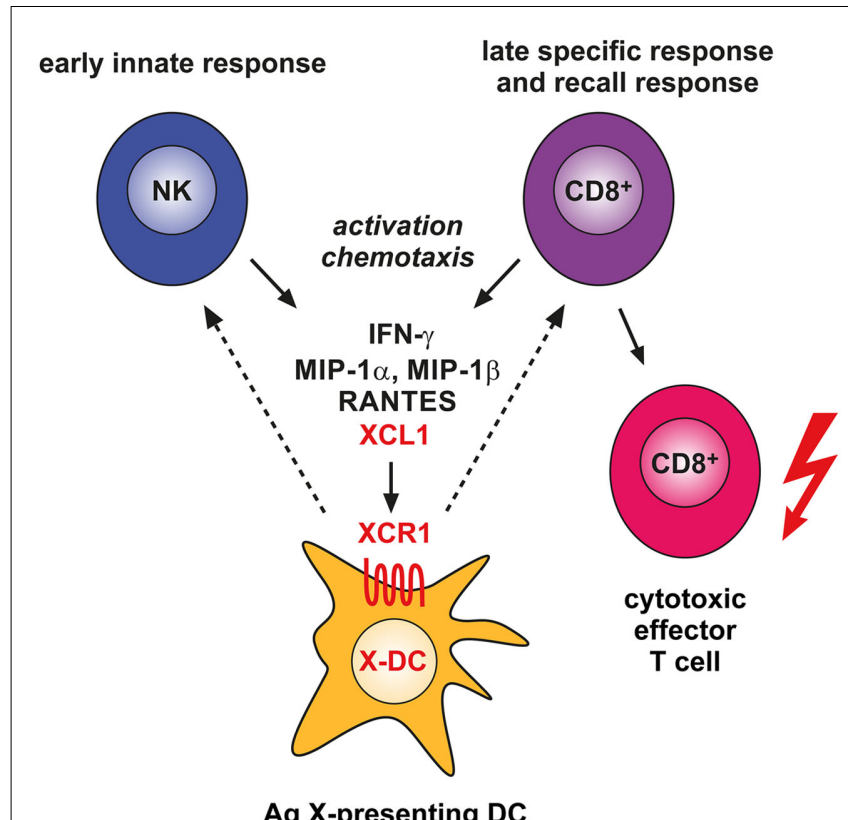

FIGURE 1 | Involvement of the XCL1-XCR1 communication axis in the innate and adaptive cytotoxic responses to cross-presented microbial and tumor antigens. Secretion of the chemokine XCL1 by activated NK cells specifically attracts XCR1-expressing DCs capable of antigen cross-presentation. This ensures an effective communication between these cells in the innate phase of the immune response. In the adaptive phase, secretion of $X C L 1$ by activated $C D 8^{+} T$ cells optimizes the dialog with antigen cross-presenting DCs and facilitates the differentiation of $\mathrm{CD} 8^{+} \mathrm{T}$ cells to cytotoxic effector cells.

(Dorner et al., 2002). XCR $1^{+}$DCs are the ideal communication partners for $\mathrm{CD} 8^{+} \mathrm{T}$ cells, since they optimally cross-present antigen and integrate any inflammatory signals, so $\mathrm{CD} 8^{+} \mathrm{T}$ cells can be tolerized or receive a "license to kill."

One additional factor in this complex interplay may be the special capacity of XCR1 $1^{+}$DCs to take up certain forms of antigen. Uptake of L. monocytogenes by $\mathrm{CD} 8^{+} \mathrm{DCs}$ (which now have to be reconsidered as XCR $1^{+}$DCs) is critical for infection with Listeria (Neuenhahn et al., 2006; Edelson et al., 2011), and possibly also for the development of immunity against this pathogen. Thus, the special ability of XCR $1^{+}$DCs to take up certain (intracellular?) pathogens defines them as ideal DCs for instructing cytotoxic effector cells of the innate and adaptive immune systems to eliminate infected cells in the periphery. This mechanism appears important, since pathogens, once "hidden" in infected cells, are otherwise "invisible" to the immune system. A similar function of $\mathrm{XCR} 1^{+}$DCs can be hypothesized in the surveillance of the body for tumor antigens. Live or dead cancerous cells taken up by XCR1 ${ }^{+}$ DCs will be digested and processed, and any tumor antigens will be cross-presented by the MHC-class I molecules to $\mathrm{CD} 8^{+} \mathrm{T}$ cells. One has to assume, however, that the recognition of "altered self" from cancerous tissue by $\mathrm{CD} 8^{+} \mathrm{T}$ cells has to be accompanied by some "adjuvant" signal to initiate a cytotoxic response against the tumor. Otherwise, a tolerance reaction to "altered self" may result.
The exquisite specificity of XCR1 expression may in future be exploited for vaccination purposes. Almost a decade ago, the groups of Steinman and Nussenzweig had pioneered the concept of antigen targeting to DCs by employing a mAb directed to CD205 (Hawiger et al., 2001). Such a concept promises to lower the antigen dose required to induce optimal immunity. More importantly, by targeting antigen to functionally different DC subsets, it offers the possibility to elicit highly specific immune responses. Based on such a concept, one can envisage future "designer vaccines" which address various components of the immune system to a different extent and thus elicit a protective immune response tailored to given pathogens. Early studies employing antibodies directed to CD205 convincingly demonstrated that potent cytotoxic CD8 ${ }^{+}$ $\mathrm{T}$ cell immunity can be induced when the targeted antigen is administered together with agents having adjuvant activity on DCs (Bonifaz et al., 2002). Similar results were obtained later with mAb directed to Clec9A/DNGR-1 (Caminschi et al., 2008; Sancho et al., 2008). None of the mAb used for DC-targeted antigen delivery to date, however, recognizes only one functional DC subset. For example, CD205 in the mouse is expressed on a variety of cells, including B cells, as well as thymic and intestinal epithelia (Witmer-Pack et al., 1995), Clec9A/DNGR-1 on pDCs, and a subset of $\mathrm{CD} 24^{+}$blood DCs (Caminschi et al., 2008; Sancho et al., 2008). This may not be disadvantageous for the induction of the desired immune response, but the lack of "absolute" specificity for a functional DC subset runs against the "designer vaccine" concept, in which only one component of the immune system is specifically addressed. Thus, ideally, antigen could be selectively delivered to B cells, or pDCs, or any of the functionally different DC subsets (or any desired combination thereof). XCR1 as a target molecule appears to fulfill such an ideal. By being expressed only on the subset of DCs preferentially interacting with components of cytotoxic immunity (NK cells and CD8 ${ }^{+}$ $\mathrm{T}$ cells), it holds the promise of an entry port for vaccines against intracellular pathogens like P. falciparum or M. tuberculosis. Initial targeting tests performed with OVA recombinantly engineered to the chemokine ligand XCL1 or with OVA chemically coupled to the XCR1-specific mAb MARX10 gave very promising results. By combining this type of antigen delivery with adjuvants, a potent and specific in vivo cytotoxicity could be achieved (own unpublished results). Further tests have to be performed, however, to demonstrate that this response is highly selective and does not address other components of the immune system. Thus, XCR1 appears as an attractive target molecule for the "designer vaccine" concept.

All antigen targeting experiments were performed in the mouse and have to be regarded as model systems only. In the human system, the phenotype and function of DCs is less well understood, since most of the data has been obtained with in vitro generated monocyte-derived DCs, which may only partially reflect DC function in vivo. In the relatively few studies with primary human $\mathrm{DCs}, \mathrm{CD} 304^{+} \mathrm{pDCs}$, and conventional DCs encompassing the $\mathrm{CD} \mathrm{C}^{+}\left(\mathrm{BDCA}^{-}{ }^{+}\right), \mathrm{CD} 16^{+}$, and $\mathrm{CD} 141^{+} \mathrm{DC}\left(\mathrm{BDCA}^{-} 3^{+}\right)$subsets could be identified in the peripheral blood (Dzionek et al., 2000; MacDonald et al., 2002; Piccioli et al., 2007; for review see Ju et al., 2010). Extensive gene expression comparison suggested that $\mathrm{CD} 141^{+}$DCs may correspond to murine $\mathrm{CD} 8^{+} \mathrm{DCs}$ (Robbins 
et al., 2008). Recent experimental work has confirmed this hypothesis: XCR1 was found to be selectively expressed in CD141 ${ }^{+}$DCs and not in other cells (Bachem et al., 2010; Crozat et al., 2010), and $\mathrm{CD} 141^{+}$DCs were the only DC subset migrating to XCL1 (Bachem et al., 2010). Further, primary CD141 ${ }^{+}$DCs were found to be particularly capable of antigen cross-presentation, when tested in vitro with soluble or cell-associated antigen (Bachem et al., 2010; Crozat et al., 2010; Jongbloed et al., 2010). These data collectively indicated that $\mathrm{CD} 141^{+}$DCs are the homologs of murine $\mathrm{CD}^{+}$DCs and suggest that the lessons learned in the mouse most likely will also hold true in the human. This view is supported by the close structural resemblance of mouse and human XCL1 and mouse and human XCR1. Moreover, the expression pattern of human XCL1 (activated NK cells and CD8 ${ }^{+}$ T cells; Müller et al., 1995; Hedrick et al., 1997; Blaschke et al., 2003) appears very similar to the XCL1 expression profile in the mouse. Thus, the CD $141^{+}$DCs are most likely specialized on the surveillance of intracellular pathogens and also aberrant antigens

\section{REFERENCES}

Bachem, A., Güttler, S., Hartung, E., Ebstein, F., Schaefer, M., Tannert, A., Salama, A., Movassaghi, K., Opitz, C., Mages, H. W., Henn, V., Kloetzel, P. M., Gurka, S. and Kroczek, R. A. (2010). Superior antigen crosspresentation and XCR1 expression define human $\mathrm{CD}_{11 \mathrm{c}^{+}} \mathrm{CD} 141^{+}$ cells as homologues of mouse CD8 ${ }^{+}$ dendritic cells. J. Exp. Med. 207, 1273-1281.

Bar-On, L., Birnberg, T., Lewis, K. L., Edelson, B. T., Bruder, D., Hildner, K., Buer, J., Murphy, K. M., Reizis, B., and Jung, S. (2010). CX3CR1 ${ }^{+}$ $\mathrm{CD} 8 \alpha^{+}$dendritic cells are a steadystate population related to plasmacytoid dendritic cells. Proc. Natl. Acad. Sci. U.S.A. 107, 14745-14750.

Blaschke, S., Middel, P., Dorner, B. G., Blaschke, V., Hummel, K. M., Kroczek, R. A., Reich, K., Benoehr, P., Koziolek, M., and Muller, G. A. (2003). Expression of activation-induced, $\mathrm{T}$ cellderived, and chemokine-related cytokine/lymphotactin and its functional role in rheumatoid arthritis. Arthritis Rheum. 48, 1858-1872.

Bleul, C. C., Fuhlbrigge, R. C., Casasnovas, J. M., Aiuti, A. and Springer, T. A. (1996). A highly efficacious lymphocyte chemoattractant, stromal cell-derived factor 1 (SDF-1). J. Exp. Med. 184, 1101-1109.

Bonifaz, L., Bonnyay, D., Mahnke, K., Rivera, M., Nussenzweig, M. C. and Steinman, R. M. (2002). Efficient targeting of protein antigen to the dendritic cell receptor DEC-205 in the steady state leads to antigen presentation on major histocompatibility complex class I products and peripheral $\mathrm{CD}^{+} \mathrm{T}$ cell tolerance. $J$. Exp. Med. 196, 1627-1638.
Caminschi, I., Proietto, A. I., Ahmet, F., Kitsoulis, S., Shin, T. J., Lo, J. C., Rizzitelli, A., Wu, L., Vremec, D., van Dommelen, S. L., Campbell, I. K., Maraskovsky, E., Braley, H., Davey, G. M., Mottram, P., van, d. V., Jensen, K., Lew, A. M., Wright, M. D., Heath, W. R., Shortman, K., and Lahoud, M. H. (2008). The dendritic cell subtype-restricted C-type lectin Clec9A is a target for vaccine enhancement. Blood 112, 3264-3273.

Crozat, K., Guiton, R., Contreras, V., Feuillet, V., Dutertre, C. A., Ventre, E., Vu Manh, T. P., Baranek, T., P., Hosmalin, A., Schwartz-Cornil, I. and Dalod, M. (2010). The XC chemokine receptor 1 is a conserved selective marker of mammalian cells homologous to mouse CD $8 \alpha^{+}$dendritic cells. J. Exp. Med. 207, 1283-1292.

Crozat, K., Tamoutounour, S., Vu Manh, T. P., Fossum, E., Luche, H., Ardouin, L., Guilliams, M., Azukizawa, H., Bogen, B., Malissen, B., and Dalod, M. (2011). Cutting edge: expression of XCR1 defines mouse lymphoidtissue resident and migratory dendritic cells of the $\mathrm{CD} 8 \alpha^{+}$type. $J$. Immunol. 187, 4411-4415.

den Haan, J. M., Lehar, S. M., and Bevan, M. J. (2000). $\mathrm{CD}^{+}$but not $\mathrm{CD} 8^{-}$ dendritic cells cross-prime cytotoxic T cells in vivo. J. Exp. Med. 192, 1685-1696.

Dorner, B., Müller, S., Entschladen, F., Schröder, J. M., Franke, P., Kraft, R., Friedl, P., Clark-Lewis, I., and Kroczek, R. A. (1997). Purification, structural analysis, and function of natural ATAC, a cytokine secreted by $\mathrm{CD}^{+} \mathrm{T}$ cells. J. Biol. Chem. 272, 8817-8823. Storset, A. K., Marvel, J., Boudinot,

originating from cancerous tissue. Similar to the mouse system, they can be expected to closely cooperate with cells of cytotoxic immunity.

Considering all available functional data, XCR1 also in the human appears to be an ideal target for antigen delivery. Different from CD205, which in the human is expressed on CD11 $\mathrm{c}^{+}$ DC, monocytes, pDC, NK cells, and T cells (Kato et al., 2006), and Clec9A/DNGR-1, which is expressed on CD141 ${ }^{+}$DC, but also found on a subset of $\mathrm{B}$ cells and $\mathrm{CD} 14^{+} \mathrm{CD}^{-} 6^{-}$monocytes (Caminschi et al., 2008; Huysamen et al., 2008), expression of XCR1 is restricted to CD141 ${ }^{+}$DCs. Given this selectivity and the functional association with antigen cross-presentation, XCR1 emerges as a prime candidate for vaccines designed to induce selective cytotoxic immunity in man.

\section{ACKNOWLEDGMENTS}

This work was supported by grants of the Wilhelm-SanderFoundation and the Deutsche Forschungsgemeinschaft TR52.

Dorner, B. G., Dorner, M. B., Zhou, X., Opitz, C., Mora, A., Güttler, S., Hutloff, A., Mages, H. W., Ranke, K., Schaefer, M., Jack, R. S., Henn, V. and Kroczek, R. A. (2009). Selective expression of the chemokine receptor XCR1 on cross-presenting dendritic cells determines cooperation with $\mathrm{CD}^{+} \mathrm{T}$ cells. Immunity 31, 823-833.

Dorner, B. G., Scheffold, A., Rolph, M. S., Hüser, M. B., Kaufmann, S. H., Radbruch, A., Flesch, I. E., and Kroczek, R. A. (2002). MIP-1 $\alpha$, MIP-1 $\beta$, RANTES, and ATAC/lymphotactin function together with IFN- $\gamma$ as type 1 cytokines. Proc. Natl. Acad. Sci. U.S.A. 99, 6181-6186.

Dorner, B. G., Smith, H. R., French, A. R., Kim, S., Poursine-Laurent, J., Beckman, D. L., Pingel, J. T., Kroczek, R. A., and Yokoyama, W. M. (2004). Coordinate expression of cytokines and chemokines by NK cells during murine cytomegalovirus infection. J. Immunol. 172 3119-3131.

Dorner, B. G., Steinbach, S., Hüser, M. B., Kroczek, R. A., and Scheffold, A. (2003). Single-cell analysis of the murine chemokines MIP- $1 \alpha$, MIP-1 $\beta$, RANTES, and ATAC/lymphotactin by flow cytometry. J. Immunol. Methods 274 83-91.

Dzionek, A., Fuchs, A., Schmidt, P. Cremer, S., Zysk, M., Miltenyi, S., Buck, D. W., and Schmitz, J. (2000). BDCA-2, BDCA-3, and BDCA-4: three markers for distinct subsets of dendritic cells in human peripheral blood. J. Immunol. 165, 6037-6046.

Edelson, B. T., Bradstreet, T. R., Hildner, K., Carrero, J. A., Frederick, K.
E., Kc, W., Belizaire, R., Aoshi, T., Schreiber, R. D., Miller, M. J., Murphy, T. L., Unanue, E. R., and Murphy, K. M. (2011). CD $8 \alpha^{+}$dendritic cells are an obligate cellular entry point for productive infection by Listeria monocytogenes. Immunity 35 236-248.

Hawiger, D., Inaba, K., Dorsett, Y., Guo, M., Mahnke, K., Rivera, M., Ravetch J. V., Steinman, R. M. and Nussenzweig, M. C. (2001). Dendritic cells induce peripheral $\mathrm{T}$ cell unresponsiveness under steady state conditions in vivo. J. Exp. Med. 194, 769-779.

Hedrick, J. A., Saylor, V., Figueroa D., Mizoue, L., Xu, Y., Menon, S., Abrams, J., Handel, T., and Zlotnik, A. (1997). Lymphotactin is produced by NK cells and attracts both NK cells and $\mathrm{T}$ cells in vivo. J. Immunol. 158, 1533-1540

Heiber, M., Docherty, J. M., Shah, G. Nguyen, T., Cheng, R., Heng, H. H., Marchese, A., Tsui, L. C., Shi, X., George, S. R., and O’Dowd, B. F. (1995). Isolation of three novel human genes encoding $G$ proteincoupled receptors. DNA Cell Biol. 14, 25-35.

Huysamen, C., Willment, J. A., Dennehy, K. M., and Brown, G. D. (2008) CLEC9A is a novel activation Ctype lectin-like receptor expressed on $\mathrm{BDCA}^{+}$dendritic cells and a subset of monocytes. J. Biol. Chem. 283, 16693-16701.

Johnston, B., Kim, C. H., Soler, D., Emoto, M., and Butcher, E. C. (2003). Differential chemokine responses and homing patterns of murine TCR $\alpha \beta$ NKT cell subsets. J. Immunol. 171, 2960-2969. 
Jongbloed, S. L., Kassianos, A. J., McDonald, K. J., Clark, G. J., Ju, X., Angel, C. E., Chen, C. J., Dunbar, P. R., Wadley, R. B., Jeet, V., Vulink, A. J., Hart, D. N. and Radford, K. J. (2010). Human CD141 ${ }^{+}$ $(\mathrm{BDCA}-3)^{+}$dendritic cells (DCs) represent a unique myeloid DC subset that cross-presents necrotic cell antigens. J. Exp. Med. 207, 1247-1260.

Ju, X., Clark, G., and Hart, D. N. (2010). Review of Human DC Subtypes. Methods Mol. Biol. 595, 3-20.

Kato, M., McDonald, K. J., Khan, S., Ross, I. L., Vuckovic, S., Chen, K., Munster, D., MacDonald, K. P., and Hart, D. N. (2006). Expression of human DEC-205 (CD205) multi lectin receptor on leukocytes. Int. Immunol. 18, 857-869.

Kelner, G. S., Kennedy, J., Bacon, K. B., Kleyensteuber, S., Largaespada, D. A., Jenkins, N. A., Copeland, N. G., Bazan, J. F., Moore, K. W., Schall, T. J., and Zlotnik, A. (1994). Lymphotactin: a cytokine that represents a new class of chemokine. Science 266, 1395-1399.

MacDonald, K. P., Munster, D. J., Clark, G. J., Dzionek, A., Schmitz, J., and Hart, D. N. (2002). Characterization of human blood dendritic cell subsets. Blood 100, 4512-4520.

Moser, B., and Loetscher, P. (2001). Lymphocyte traffic control by chemokines. Nat. Immunol. 2, 123-128.

Müller, S., Dorner, B., Korthäuer, U., Mages, H. W., D’Apuzzo, M., Senger,
G., and Kroczek, R. A. (1995). Cloning of ATAC, an activationinduced, chemokine-related molecule exclusively expressed in $\mathrm{CD} 8^{+}$ T lymphocytes. Eur. J. Immunol. 25, 1744-1748.

Neuenhahn, M., Kerksiek, K. M., Nauerth, M., Suhre, M. H., Schiemann, M., Gebhardt, F. E., Stemberger, C., Panthel, K., Schroder, S., Chakraborty, T., Jung, S., Hochrein, H., Russmann, H., Brocker, T., and Busch, D. H. (2006). CD8 $\alpha^{+}$dendritic cells are required for efficient entry of Listeria monocytogenes into the spleen. Immunity 25 , 619-630.

Pamer, E. G. (2004). Immune responses to Listeria monocytogenes. Nat. Rev. Immunol. 4, 812-823.

Piccioli, D., Tavarini, S., Borgogni, E., Steri, V., Nuti, S., Sammicheli, C., Bardelli, M., Montagna, D., Locatelli, F., and Wack, A. (2007). Functional specialization of human circulating $\mathrm{CD} 16$ and CD1c myeloid dendriticcell subsets. Blood 109, 5371-5379.

Robbins, S. H., Walzer, T., Dembele, D., Thibault, C., Defays, A., Bessou, G., Xu, H., Vivier, E., Sellars, M., Pierre, P., Sharp, F. R., Chan, S., Kastner, P., and Dalod, M. (2008). Novel insights into the relationships between dendritic cell subsets in human and mouse revealed by genome-wide expression profiling. Genome Biol. 9, R17.

Sancho, D., Mourao-Sa, D., Joffre, O. P., Schulz, O., Rogers, N. C., Pennington, D. J., Carlyle, J. R., and Reis e
Sousa, C. (2008). Tumor therapy in mice via antigen targeting to a novel, DC-restricted C-type lectin. J. Clin Invest. 118, 2098-2110.

Shan, L., Qiao, X., Oldham, E., Catron, D., Kaminski, H., Lundell, D., Zlotnik, A., Gustafson, E., and Hedrick, J. A. (2000). Identification of viral macrophage inflammatory protein (vMIP)-II as a ligand for GPR5/XCR1. Biochem. Biophys. Res. Commun. 268, 938-941.

Shortman, K., and Heath, W. R. (2010). The $\mathrm{CD}^{+}$dendritic cell subset. Immunol. Rev. 234, 18-31.

Vremec, D., Pooley, J., Hochrein, H., Wu, L., and Shortman, K. (2000). CD4, and CD8 expression by dendritic cell subtypes in mouse thymus, and spleen. J. Immunol. 164, 2978-2986.

Witmer-Pack, M. D., Swiggard, W. J., Mirza, A., Inaba, K., and Steinman, R. M. (1995). Tissue distribution of the DEC-205 protein that is detected by the monoclonal antibody NLDC-145. II. Expression in situ in lymphoid and nonlymphoid tissues. Cell. Immunol. 163 157-162.

Yoshida, T., Imai, T., Kakizaki, M., Nishimura, M., Takagi, S., and Yoshie, O. (1998). Identification of single C motif-1/lymphotactin receptor XCR1. J. Biol. Chem. 273 16551-16554.

Yoshida, T., Imai, T., Kakizaki, M., Nishimura, M., and Yoshie, O. (1995). Molecular cloning of a novel $\mathrm{C}$ or gamma type chemokine, SCM1. FEBS Lett. 360, 155-159.
Yoshida, T., Imai, T., Takagi, S., Nishimura, M., Ishikawa, I., Yaoi, T., and Yoshie, O. (1996). Structure and expression of two highly related genes encoding SCM-1/human lymphotactin. FEBS Lett. 395, 82-88.

Yoshida, T., Izawa, D., Nakayama, T. Nakahara, K., Kakizaki, M., Imai, T., Suzuki, R., Miyasaka, M., and Yoshie, O. (1999). Molecular cloning of mXCR1, the murine SCM1/lymphotactin receptor. FEBS Lett. $458,37-40$

Conflict of Interest Statement: The authors declare that the research was conducted in the absence of any commercial or financial relationships that could be construed as a potential conflict of interest.

Received: 12 December 2011; accepted: 26 January 2012; published online: 10 February 2012.

Citation: Kroczek RA and Henn V (2012) The role of XCR1 and its ligand XCL1 in antigen cross-presentation by murine and human dendritic cells. Front. Immun. 3:14. doi: 10.3389/fimmu.2012.00014

This article was submitted to Frontiers in Antigen Presenting Cell Biology, a specialty of Frontiers in Immunology. Copyright () 2012 Kroczek and Henn. This is an open-access article distributed under the terms of the Creative Commons Attribution Non Commercial License, which permits non-commercial use, distribution, and reproduction in other forums, provided the original authors and source are credited. 